\title{
Editorial
}

\section{Bibliotecas públicas em tempos de desinformação}

É com imensa alegria e honra que recebi o convite para escrever um editorial para a "Ciência da Informação em Revista". Apesar do prazo exíguo que me foi dado (motivo pelo qual me desculpo pelas prováveis falhas e lacunas), não poderia me furtar a este convite, vindo de uma equipe editorial com a qual tenho convivido e aprendido ao longo dos últimos anos. Ainda mais porque neste oitavo volume a revista traz na capa dos fascículos uma justa homenagem a instituições culturais do Estado de Alagoas, com ilustrações do Museu Théo Brandão de Antropologia e Folclore, pertencente à Universidade Federal de Alagoas, depois o Arquivo Público de Alagoas e, agora, da Biblioteca Pública Estadual Graciliano Ramos. Localizados no histórico bairro do Jaraguá, em Maceió, estes equipamentos culturais compartiIham mais do que a proximidade geográfica, um histórico de abandono e descaso por parte do poder público e uma árdua luta de suas equipes para oferecer os serviços de que dispõem para a população que ainda usufrui.

Não por acaso, as três instituições intercalaram períodos de carência de manutenção, fechamento, reformas e restauração, reabertura e reinauguração. Olhando para seu passado, considerando a situação e a conjuntura no presente, cabe questionarmos o seu futuro, não apenas particularmente da Biblioteca Graciliano Ramos, mas ampliadamente: as bibliotecas públicas ainda servem para algo? Para muitos a resposta é simples: o destino das bibliotecas é o seu completo desaparecimento. Advogam para isso principalmente a criação e o incremento constantes das novas tecnologias e mídias muito mais atrativas do que o velho e desgastado livro, que teria enfim chegado à sua obsolescência depois de alguns milênios sendo utilizado e um dos principais motivos para que os homens tenham criado - paradoxalmente - as tecnologias que em tese substituem os antigos e pesados livros.

Recentemente, um artigo ${ }^{1}$ de opinião publicado em um renomado jornal exemplifica esse pessimismo com o futuro das bibliotecas (incluindo, claro, as públicas). No texto, o autor descreve a sua experiência na juventude com as bibliotecas e demonstra que não compreende os diferentes tipos de bibliotecas, suas particularidades e objetivos. Bibliotecas públicas fazendo a vez de bibliotecas escolares é algo tão comum no Brasil que o senso comum passou a entender como este um de seus objetivos e funções. Ao contrapor bibliotecas públicas e bibliotecas nacionais o autor amplia mais a confusão. Bibliotecas escolares, públicas e nacionais, para citar apenas três tipos, têm funções diferentes. Bibliotecas não são depósitos de livros. Apenas as bibliotecas nacionais podem ter como objetivo acumular uma quantidade enorme de livros e documentos, mas isso porque têm como uma de suas funções salvaguardar a produção intelectual e cultural da nação, registradas em livros e demais suportes.

Mas então, atualmente, na chamada Era digital, qual o papel das bibliotecas públicas? Não há dúvidas de que quantidades gigantescas de informação estão disponíveis àqueles que possuem as condições materiais para acessá-las. Mas isso tornou a nossa sociedade "mais bem informada"? Não deixa de ser curioso como que, em tempos de desinformação e fake-news, ainda precisamos advogar pela importância das bibliotecas. Teria a desinforma- 
ção se alastrado tanto e causado tantos estragos para o nosso país se a nossa população estivesse alfabetizada e letrada informacionalmente ${ }^{2}$ ? Em outras palavras, se a população soubesse minimante selecionar informações, buscar e consultar fontes de informações confiáveis, ler de forma crítica e questionadora? E a questão da informação é apenas um aspecto de que tratam as bibliotecas, que não devem ser vistas como depósitos de livros, mas como espaços com múltiplas funções e atividades, todas elas amparadas ou desenvolvidas a partir de seus acervos, em geral, livros.

Bibliotecas podem ser espaços de convívio, de convivência; de descobertas, de aprendizado e de conhecimento; de entretenimento e diversão; de desenvolvimento pessoal, cultural e econômico; de cuidar do meio ambiente e de pensar a sustentabilidade, entre tantas outras. Além disso, em tempos de intolerância e desrespeito para com a vida, as bibliotecas podem ser um lugar para se aprender e cultivar a empatia, nos colocando no lugar dos outros, por meio do mundo da leitura. Isso tudo é possível, mas apenas se houver vontade política e interesse da sociedade. E é claro que estas atividades podem também usar das novas tecnologias como aliada.

Como se vê, este texto apresenta mais perguntas do que respostas. Seu objetivo é, primeiro, levantar questões e instigar debates. Não podemos adivinhar qual será o destino das bibliotecas. Mas uma coisa é certa: se no Brasil as bibliotecas 'morrerem' (para usar uma expressão do matemático e bibliotecário Shiyali R. Ranganathan (1892-1972), para quem bibliotecas são organismos em crescimento), será, não devido ao desenvolvimento de novas tecnologias mais atraentes e acessíveis, mas fruto de um conjunto de decisões que a fizeram definhar até os seus últimos dias.

\section{Iuri Rocio Franco Rizzi}

Doutor em Ciência da Informação

Professor do Curso de Biblioteconomia

Universidade Federal de Alagoas

1 FARIAS, Tom. Na era digital, destino das bibliotecas talvez seja servir de cenário para selfies.

Folha de São Paulo, 9 jan. 2022.

2 Do termo "letramento informacional". 